Uganda Journal of Agricultural Sciences by National Agricultural Research Organisation is licensed under a Creative Commons Attribution 4.0 International License.

Based on a work at www.ajol.info

\title{
Household perception of climate change in wetland adjacent areas in Uganda
}

\author{
F. Yikii ${ }^{1,2}$, B. Bashaasha ${ }^{3}$ and N. Turyahabwe
}
${ }^{1}$ Department of Forestry, Biodiversity and Tourism, School of Forestry, Environmental and Geographical Sciences, Makerere University, P. O. Box 7062, Kampala, Uganda ${ }^{2}$ Department of Environmental Management, School of Forestry, Environmental and Geographical Sciences, Makerere University, P. O. Box 7062, Kampala, Uganda ${ }^{3}$ Department of Agribusiness and Natural Resource Economics, School of Agricultural Sciences, Makerere University, P. O. Box 7062, Kampala, Uganda
${ }^{4}$ Department of Extension and Innovation Studies, School of Agricultural Sciences, Makerere University, P. O. Box 7062, Kampala, Uganda

Author for correspondence: fyikii@gmail.com,fyikii@caes.mak.ac.ug

Climate change is a major cause of food insecurity in developing countries, like Uganda where the poor people and small scale farmers have limited options for adaptation. Households adjacent to wetlands often adapt to climate change by depending on them for food security. However, interventions for climate change adaptation in developing countries are often poorly targeted due to insufficient data on climate trends. The objective of this study was to determine household perception of climate change in wetland adjacent areas, to inform climate change and adaptation policy in Uganda. The study was conducted at two sites, Lake Nakivale wetland system in Isingiro district (south-western Uganda) and Lake Kyoga basin wetland systems in Pallisa district (eastern Uganda). The study employed a cross sectional design, using a semi-structured questionnaire, and surveyed a total of 520 households. Results of the study show that a majority $\mathbf{9 2 \%}$ ) of the households were aware of climate change. Climate change was perceived by households in form of prolonged dry weather $(\mathbf{5 4 \%})$ and hotter and drier seasons $(34 \%)$. Over $90 \%$ of the respondents had noticed climate change in various forms: increased temperature ( $92 \%$ ), decreased rainfall ( $95 \%$ ), changes in the length of seasons $(97 \%)$, more frequent droughts $(\mathbf{9 3 \%})$, more severe droughts $(\mathbf{9 2} \%)$ and more severe floods in Pallisa. Households perceived climate change in the form of increased temperatures and droughts, and generally had a gloomy outlook for the future, insisting that climate change will be more severe than currently experienced. More households in Isingiro district perceived climate change to be more severe in the future than expected $\left(\chi^{2}(2)=43.67, P<0.001\right)$. Owing to the perception of more frequent and severe droughts and reduced rainfall, households around wetlands will continue to use wetlands for farming and other livelihood needs. Thus, unless 
wetland farmers (a) integrate wetland conservation by employing climate smart practices like minimum tillage, soil and water conservation, and (b) diversify their livelihoods through commercially viable initiatives like fish farming, household food security and sustainability of wetlands will be further jeopardized.

Key words: Adaptation, food insecurity, rainfall

\section{Introduction}

Climate change is currently an important driver of food insecurity in the world, with its effects more pronounced in subSaharan Africa than elsewhere (Godfray et al., 2010; Mearns and Norton, 2010; Godfray and Garnett, 2014). Climate change significantly contributes to the loss and degradation of wetlands and its biological diversity, leading to food insecurity (MEA, 2005a, 2005b). According to the Intergovernmental Panel on Climate Change (IPCC) (IPCC, 2007), the properties of climate whose variation predominantly results into climate change, are surface variables such as temperature, precipitation and wind. Therefore, climate change is generally manifested through increase in temperatures (Hansen et al., 2012), prolonged droughts and floods, including storms (Kuperman, 2011).

Inequalities in access to wetland resources exacerbate the effects of climate change on food security in the wetland areas. Studies have, for example shown that failure to integrate access to wetlands resources, especially for the poor people denies them access to safe drinking water and adequate sanitation, leading to food insecurity (Horwitz and Finlayson, 2011; Horwitz et al., 2012). To elaborate the effect of climate change across the value chain of food security in wetland areas, Horwitz et al. (2012) observed that climate change stresses agricultural production, fisheries resources; and leads to food shortage, besides affecting food quality and food distribution, thereby causing malnutrition and deterioration of human health. For example, high temperatures and droughts affect crop yields and lead to food shortages among communities (Godfray et al., 2010; Lobell et al., 2011). Floods and storms commonly destroy roads, bridges and other transport infrastructure, thus cutting off food supplies to the markets (Handmer et al., 2012). Bad weather also affects postharvest food processing thus causing postharvest food losses in communities where post-harvest technology is poor.

A study of the contribution of wetlands to food security in Uganda revealed that majority of the households in the wetlands experienced food insecurity due to climate change (Turyahabwe et al., 2013). They indicated that food insecurity in Uganda tends to coincide with extreme weather events such as prolonged droughts and heavy rains; whereby wetlands provide a food security safety net for households particularly during droughts. This is because of the ability of wetlands to store moisture in the soil for long periods. Although Turyahabwe et al. (2013) suggested that households in the neighborhoods of wetlands use the wetlands for adaptation to climate change, it is not clear as to how climate change is manifested and perceived by households in wetland adjacent communities in the country. Moreover, this information is required because adaptation rather than mitigation is recommended as a priority strategy for addressing climate change 
effects especially in developing countries that are already struggling with its consequences (Mearns and Norton, 2010; Ministry of Water and Environment, 2012).

Climate change adaptation in the SubSaharan Africa (SSA) is, however, constrained by low levels of information and awareness on climate change amongst policy-makers. This is because of the relatively scant data and information on climate change, and the unreliable observational data and climate projections in the region (Jones, 2010). Thus, information on perception of climate change by farmers and households is essential for influencing climate change policy (Deressa et al., 2011). Secondly, interventions to adapt to the effects of climate change on food security require an understanding of how climate change is manifested in the wetland areas, especially in the local context and with the local people to guide decision making, as resource constrained people may resort to options that actually worsen the situation (Government of Uganda, 2007). In addition, perception of climate change is already an important tool that households use for making decisions and taking actions regarding farming in the circumstances of climate change (Denboba, 2005; Mertz et al., 2009; Olorunfemi, 2009; Kisauzi et al., 2012).

Therefore, this study is framed on the following premises: first of all, households adapt to climate change by responding to their perception that the climate is changing (Maddison, 2007); secondly, household perceptions of climate change is a source of stimuli for the innovation they require in order to cope with food insecurity as a consequence of climate change (Ndambiri et al., 2013). The objectives of the study were thus to investigate the (a) understanding of climate change by households in wetland areas in Uganda; (b) household perception of climate change in wetland areas in Uganda; and (c) the household perception of the future of climate change in the wetland areas in Uganda.

\section{Study area}

This study was carried out in wetlands within the basin of the Lake Kyoga wetland system that stretch into Pallisa district (eastern Uganda) and wetlands within Lake Nakivale wetland system in Isingiro district (south-western Uganda) (Fig. 1). The wetland systems differ by agro-ecological zones and dominant farming systems. The L. Kyoga basin wetlands system in Pallisa district is located in the Kyoga plains agro-ecological zone, where the dominant farming system is mixed annual crop and livestock production (Ebanyat et al., 2010; Turyahabwe et al., 2013). L. Nakivale wetland system of Isingiro district is located in the south-western farmlands agro-ecological zone, where banana production and livestock rearing are dominant. In addition, the prevalence of poverty in the rural populations is less $(30 \%)$ in Isingiro district where L. Nakivale wetland system is located, than within Pallisa district (40\%) (WMD et al., 2009).

Despite their differences, the two wetland sites were selected for the study based on their bio-physical and socioeconomic similarities; for example, they are both located within the cattle corridor where rainfall pattern is erratic (Government of Uganda, 2007); they are lacustrine (adjacency to open lakes); and the perceived level of food insecurity in the neighbourhoods of the wetlands is high (Turyahabwe et al., 2013). Crucially, 

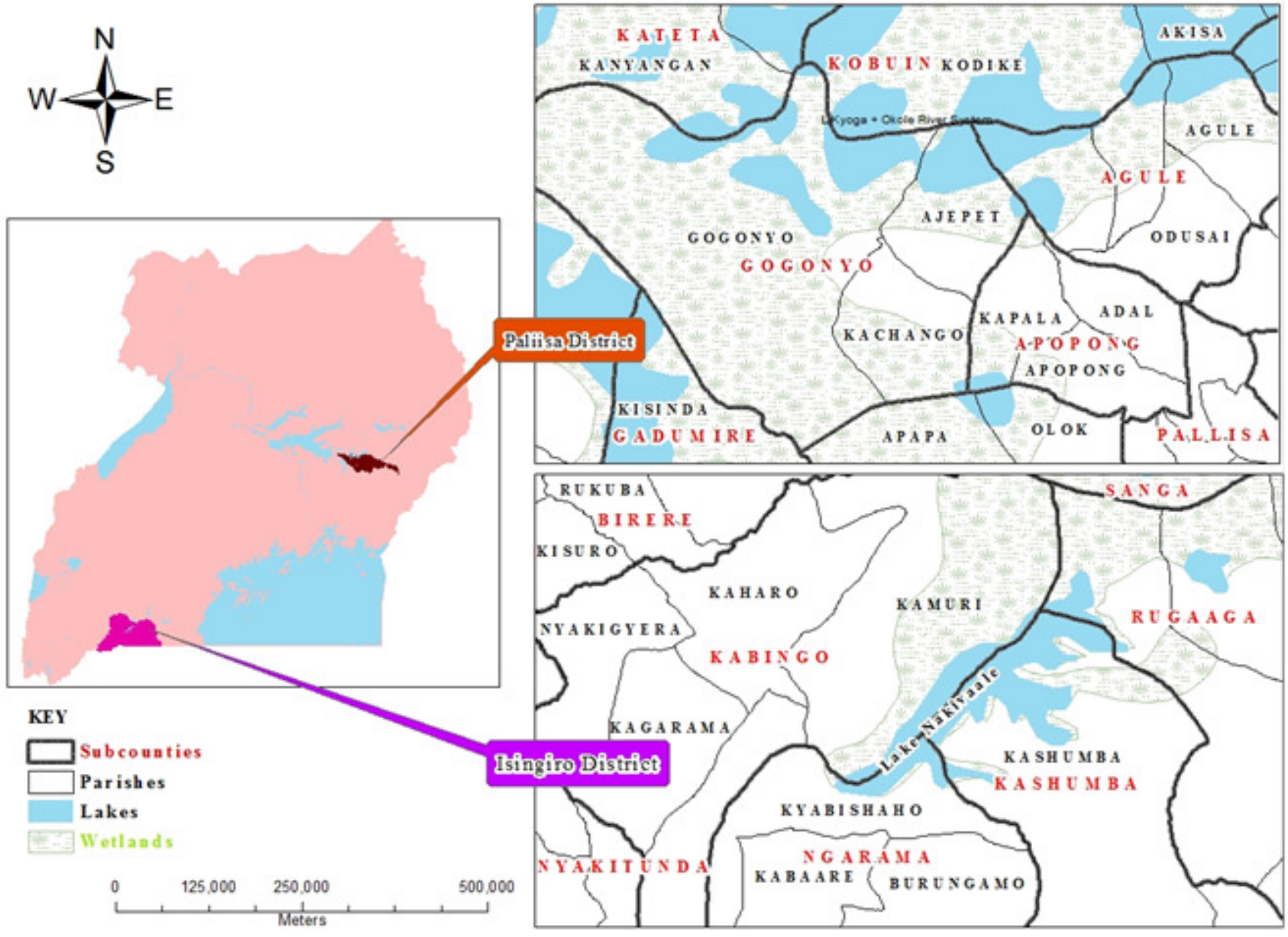

Figure 1. Map of Lake Kyoga Basin wetlands in Pallisa district and Lake Nakivale wetlands in Isingiro district. 
wetlands in the two locations are threatened by agricultural production (Mafabi, 2000). While wetlands in the L. Nakivale wetland system are highly threatened by livestock production, those in the Kyoga basin wetland systems are predominantly threatened by rice production (Mafabi, 2000). Communities in the two study sites also share livelihood strategies such as fishing, arable farming and livestock production.

\section{Data collection}

This study employed a cross sectional research design. It was based on primary data collected from late June to October 2014 using a semi-structured questionnaire. A two-stage cluster sampling technique was used to collect data. The Primary Sampling Unit (PSU) for the study was the village, which is the smallest administrative unit in Uganda. The sampling frame consisted of all the villages within parishes adjacent to the two wetland systems that had some wetland as a component of their land cover. Only villages adjacent to wetlands within Isingiro and Pallisa districts were considered for this study. Information on the list of all the villages within parishes that had wetland cover, and the number of households in such villages were accessed from the records of each district through district authorities (District Population Officer, District Natural Resources Officer, District Wetland Officer). For newly created villages where there were no reliable records for the population of households, estimates were made by the district authorities in consultation with local council authorities and other local authorities who were familiar with the wetland areas. Twenty six villages were randomly selected using the Probability Proportional to Size sampling technique to ensure that each household had an equal chance of being selected in the sample (McKinney, 2009).

The Ultimate Sampling Unit (USU) for the study was the household. A household is a suitable sampling unit because it is a dominant social and economic unit; the main unit of resource holding, production, distribution and consumption (Alelign et al., 2011). A household is also an important unit for making social and economic decisions. A household was selected as the unit of analysis in conformity with previous studies of perception of climate change (Mertz et al., 2009; Deressa et al., 2011).

Ten households were randomly selected from each of the selected villages in line with Magnani (1997) and McKinney (2009), on the premise that selection of fewer households from many villages reduces the design effect of a study. A total of 260 households were selected from each wetland system, making a total of 520 households from 52 villages. The sample size for this study was computed using Cochran's (1977) sample size formula as described by Bartlett $e t$ al. (2001).

In administering the questionnaire, respondents were first asked to give the understanding of climate change in their households. Using a three point scale (1 = agree, 2 = disagree, $3=$ do not know), they were then asked to give their views on statements framed to understand their perception of climate change in their area over the past 30 years following (Kisauzi et al., 2012). Consistent with the scale, three categories of statements were framed, namely (a) a statement on whether climate change was generally noticed; (b) statements on whether the properties of climate whose variation lead to climate change (temperature, rainfall 
and wind) have increased or decreased); and (c), statements on whether the effects of climate change are more frequent or more severe. Thirty years is the classical period set by the World Meteorological Organisation (WMO) for averaging the variables of weather (temperature, precipitation and wind) for the purpose of defining climate (WMO, 2016; IPCC, 2007). Finally, given that household perception of the future of climate change influences their future adaptation strategies, respondents were asked for their perception of the future of climate change and the reasons for their views.

\section{Data analysis}

Data for this study were analysed using descriptive statistics. A chi-square test of association was used to determine the relationship between household perception of climate change in the wetland adjacent areas (Table 2). A chi-square test of association was also carried out to determine the association between household perception of the future of climate change and agro-ecological zone.

\section{Results}

\section{Household knowledge of climate change}

Results of the study show that climate change was generally understood by households adjacent to wetlands as prolonged dry spell (drought) (53.8\%) and occurrence of hotter and drier seasons (34\%) (Table 1). To a less extent, households also understood climate change as unexpectedly heavy rains (7.4\%), low agricultural yields (1.9), and episodes of strong winds (1.1\%).

\section{Household perception of climate change}

Majority (91\%) of the respondents had noticed climate change (Table 2). About $92 \%$ of the households agreed that temperature had increased in the past thirty years; and slightly more than half (57\%) of the respondents in the L. Nakivale wetland areas perceived a decrease in temperature over the past 30 years. Only $21 \%$ of the households in L. Kyoga basin wetland areas in Pallisa

Table 1. Household understanding of climate change in wetland communities $(\mathbf{N}=520)$

\begin{tabular}{lccr}
\hline $\begin{array}{l}\text { Understanding of climate change } \\
\text { in households }\end{array}$ & \multicolumn{3}{c}{ Percentage of responses } \\
\cline { 2 - 4 } & $\begin{array}{c}\text { L. Nakivale wetland } \\
\text { system (Isingiro) } \\
(\mathrm{N}=260)\end{array}$ & $\begin{array}{c}\text { L. Kyoga Basin } \\
\text { wetland system } \\
\text { (Pallisa) }\end{array}$ & $\begin{array}{c}\text { Pooled } \\
(\mathrm{N}=520)\end{array}$ \\
\hline Prolonged dry spell (drought) & 50.6 & 57.1 & \\
Hotter and drier seasons & 39.3 & 29.0 & 53.8 \\
Heavy rains & 4.5 & 10.4 & 34.2 \\
Low yields (food shortages) & 3.4 & 0.4 & 7.4 \\
Strong winds & 0.4 & 1.9 & 1.9 \\
Loss of biodiversity & 0.7 & 1.2 & 1.1 \\
Loss of pasture & 1.1 & 0.0 & 0.6 \\
\hline
\end{tabular}

Total number of multiple responses $=526$ 
Table 2. Household perception of climate change in the communities adjacent to wetlands ( $N=520$ )

\begin{tabular}{|c|c|c|c|c|c|c|c|c|c|c|c|}
\hline \multirow[t]{3}{*}{ Perception of climate change } & \multicolumn{9}{|c|}{ Percentage of households } & \multirow[t]{3}{*}{$\chi^{2}$} & \multirow[t]{3}{*}{ P-value } \\
\hline & \multicolumn{3}{|c|}{$\begin{array}{l}\text { L. Nakivale wetland system } \\
\text { (Isingiro) }(\mathrm{N}=260)\end{array}$} & \multicolumn{3}{|c|}{$\begin{array}{l}\text { L. Kyoga Basin wetland } \\
\text { system (Pallisa) }(\mathrm{N}=260)\end{array}$} & \multicolumn{3}{|c|}{ Pooled (N=520) } & & \\
\hline & Agree & Disagree & $\begin{array}{l}\text { Don't } \\
\text { know }\end{array}$ & Agree & Disagree & $\begin{array}{l}\text { Don't } \\
\text { know }\end{array}$ & Agree & Disagree & $\begin{array}{l}\text { Don't } \\
\text { know }\end{array}$ & & \\
\hline \multicolumn{12}{|l|}{ (a) Climate change } \\
\hline $\begin{array}{l}\text { Climate changes noticed } \\
\text { (b) Climate change propertie }\end{array}$ & 96 & $2 b$ & $2 b$ & 85 & $8 \mathrm{a}$ & $7 \mathrm{a}$ & 91 & 5 & 4 & 18.976 & $0.000^{\dagger \hat{A}}$ \\
\hline Temperature increased & 87 & 5 & $8 \mathrm{a}$ & 96 & 4 & $0 \mathrm{~b}$ & 92 & 4 & 4 & 22.601 & $0.000^{\hat{A} \hat{A} \hat{A}}$ \\
\hline Temperature decreased & $57 \mathrm{a}$ & $22 b$ & $21 \mathrm{a}$ & $21 b$ & $79 a$ & $\mathrm{Ob}$ & 39 & 50 & 11 & 185.620 & $0.000^{* * *+\dagger \dagger \hat{A} \hat{A} \hat{A}}$ \\
\hline Rainfall decreased & 95 & 4 & 1 & 94 & 5 & 1 & 95 & 4 & 1 & 0.535 & $0.892^{\mathrm{f}, \mathrm{ns}}$ \\
\hline Strong winds more frequent & $55 \mathrm{~b}$ & $19 \mathrm{a}$ & $26 \mathrm{a}$ & $90 \mathrm{a}$ & $10 \mathrm{~b}$ & $0 \mathrm{~b}$ & 73 & 14 & 13 & 96.633 & $0.000^{* * * * \hat{A} \hat{A} \hat{A}}$ \\
\hline Strong winds more severe & $42 b$ & $32 \mathrm{a}$ & 26 & $88 \mathrm{a}$ & $12 \mathrm{~b}$ & 0 & 65 & 22 & 13 & 132.638 & $0.000^{* * *+\dagger \dagger}$ \\
\hline \multicolumn{12}{|l|}{ (c) Climate change effects } \\
\hline Length of seasons changed & 95 & 3 & 2 & 99 & 1 & 0 & 97 & 2 & 1 & 9.541 & $0.004^{\mathrm{f}}$ \\
\hline Floods more severe & $37 \mathrm{~b}$ & 39 & $24 \mathrm{a}$ & $74 a$ & 26 & $\mathrm{Ob}$ & 56 & 32 & 12 & 101.806 & $0.000^{* * * \hat{A} \hat{A} \hat{A}}$ \\
\hline Droughts more frequent & 91 & 4 & $5 \mathrm{a}$ & 95 & 5 & $0 \mathrm{~b}$ & 93 & 5 & 2 & 17.330 & $0.000^{\hat{A}}$ \\
\hline Droughts more severe & 87 & 9 & $4 a$ & 96 & 4 & $\mathrm{Ob}$ & 92 & 6 & 2 & 12.558 & $0.002^{\hat{A}}$ \\
\hline
\end{tabular}

ns: $-1.96<\mathrm{Z}<+1.96$ (Post hoc test not statistically significant). *,**,***: Post hoc test statistically significant for category/cell "Agree" at $\mathrm{P}<0.05$ ($1.96>Z>+1.96), P<0.01(-2.58>Z>+2.58)$, and $\mathrm{P}<0.001(-3.29>Z>+3.29)$ respectively. $\dagger, \dagger \dagger, \dagger \dagger \dagger$ : Post hoc test statistically significant for category/ cell "Disagree" at $\mathrm{P}<0.05(-1.96>\mathrm{Z}>+1.96), \mathrm{P}<0.01(-2.58>\mathrm{Z}>+2.58)$, and $\mathrm{P}<0.001(-3.29>\mathrm{Z}>+3.29)$ respectively. $\hat{\mathrm{A}}, \hat{\mathrm{A}} \hat{\mathrm{A}}, \hat{\mathrm{A}} \hat{\mathrm{A}} \hat{\mathrm{A}}: \quad$ Post hoc test statistically significant for category/cell "Don't know" at $\mathrm{P}<0.05(-1.96>\mathrm{Z}>+1.96), \mathrm{P}<0.01(-2.58>\mathrm{Z}>+2.58)$, and $\mathrm{P}<0.001(-3.29>\mathrm{Z}>+3.29)$ respectively $\mathrm{Z}$ : Standardised residual $[\mathrm{P}<0.05(-1.96>\mathrm{Z}>+1.96), \mathrm{P}<0.01(-2.58>\mathrm{Z}>+2.58)$, and $\mathrm{P}<0.001(-3.29>\mathrm{Z}>+3.29)]$ (Field, 2009). f: Fisher's Exact Test

P-Value: for Pearson $\chi^{2}$ test. a,b More/fewer households observed than expected 
agreed that temperature had decreased. There were overwhelming agreements across the study sites about the pattern of precipitation in the past thirty years; that is, rainfall had decreased (95\%), the length of seasons had changed (97\%), droughts were more frequent (93\%), and droughts were more severe $(92 \%)$ (Table 2).

There was a significant association between wetland systems (study sites) and household perception of climate change $\left(\chi^{2}(2)=18.976, \mathrm{P}<0.001\right)$ (Table $2)$. Among the households in the L. Nakivale wetland system (south-western farmlands in Isingiro district), there were fewer respondents who disagreed that climate change had taken place than expected $(\mathrm{P}<0.05)$. Similarly, the post-hoc test showed that the number of households in L. Nakivale wetland system who did not know whether climate change had occurred was fewer than expected $(\mathrm{P}<0.05)$.

The study showed a significant association between wetland systems (study sites) and household perception that (a) temperature increased $\left(\chi^{2}(2)=22.601\right.$, $\mathrm{P}<0.001)$ and (b) temperature decreased $\left(\chi^{2}(2)=185.620, \mathrm{P}<0.001\right)($ Table 2$)$. Compared with households in the Kyoga basin wetland system (Kyoga plains agroecological zone in Pallisa district), the proportion of households in L. Nakivale wetland system who did not know that temperature had increased over the past 30 years was more than expected $(\mathrm{P}<0.001)$ (Table 2). On the other hand, the number of households in L. Nakivale wetland system who agreed that temperatures had decreased were more than expected $(\mathrm{P}<0.001)$. Unlike households in L. Nakivale wetland system, fewer households in Pallisa district did not know that temperature had decreased $(\mathrm{P}<0.001)$.

Regarding winds, there was a significant association between wetland systems (study sites) and household perception of the frequency $\left(\chi^{2}(2)\right.$ $=96.633, \mathrm{P}<0.001)$ and severity $\left(\chi^{2}(2)\right.$ $=132.638, \mathrm{P}<0.001)$ of winds. Unlike the households in L. Nakivale wetland system, more households in the Kyoga plains wetland areas agreed that strong winds had become more frequent $(\mathrm{P}<0.001)$ and more severe $(\mathrm{P}<0.001)$ (Table 2$)$. In addition, there was a significant association between wetland systems and household perception of the severity of floods $\left(\chi^{2}\right.$ $(2)=101.806, \mathrm{P}<0.001)$. While households in L. Nakivale wetland system were indifferent on the severity of floods in the area over the past 30 years, majority (74\%) of those in Kyoga basin wetland areas in Pallisa believed that floods had become more severe over the same period $(\mathrm{P}<0.001)$. On the other hand, fewer households among those sampled from Kyoga basin wetland areas did not know about the increased severity of floods $(\mathrm{P}<0.001)$.

There was also a significant association between wetland systems (study sites) and household perception that the length of seasons had changed. However, the post hoc test of the association was not significant. Furthermore, the study showed that wetland systems were significantly associated with household perception of the frequency $\left(\chi^{2}(2)\right.$ $=17.330, \mathrm{P}<0.001)$ and severity $\left(\chi^{2}(2)\right.$ $=12.558, \mathrm{P}<0.01)$ of droughts. Specifically, more households in L. Nakivale wetland areas did not know whether or not droughts had become more frequent $(\mathrm{P}<0.05)$ or more severe $(\mathrm{P}<0.05)$ (Table 2$)$. 
Perception of the future of climate change

Majority (73\%) of the households in L.

Nakivale wetland system expect climate change to be more severe; while $44 \%$ of their counterparts in the Kyoga basin wetland areas in Pallisa district hold the same view (Table 3). On the other hand, about half $(47 \%)$ of the households in the Kyoga basin wetland areas in Pallisa district are uncertain about what the future holds for climate change. Overall, slightly more than half $(58 \%)$ of the households expect climate change to be more severe, and only $7 \%$ of them perceive climate change to be less severe in the future (Table 3). A chi-square test of independence showed a significant association between wetland systems (study sites) and household perception of the future of climate change $\left(\chi^{2}(2)=43.67\right.$, $\mathrm{P}<0.001)$. There were more households in L. Nakivale wetland system who perceived climate change to be more severe in the future than expected $(\mathrm{P}<0.001)$, and there were fewer of them who did not know whether climate change would be more severe in the future $(\mathrm{P}<0.001)$ (Table 3).

\section{Household pessimistic view of the future of climate change effects}

Out of the 304 households (58\%) that believed climate change will be more severe in the future (Table 3), about $48 \%$ had no particular reason for believing that climate change will be more severe in the future, $31 \%$ of them had attributed their pessimistic perception of the future of climate change to deforestation, and $6 \%$ perceive more severe climate change in the future because of the prevailing low rainfall patterns (Fig. 2). To a less extent, though, households also mentioned poor land use practices $(4.6 \%)$, lack of afforestation programmes (3.2\%), unexpected floods $(2.63 \%)$, and supernatural powers such as the will of God (1.64\%) as reasons for more severe climate change in the future.

On comparing the reasons for household perception of a more severe

Table 3. Household perception of the future of climate change $(\mathrm{N}=520)$

\begin{tabular}{lccl}
\hline $\begin{array}{l}\text { Perception of the future } \\
\text { of climate change }\end{array}$ & \multicolumn{3}{c}{ Percentage of households } \\
\cline { 2 - 4 } & $\begin{array}{c}\text { L. Nakivale wetland } \\
\text { system (Isingiro) }(\mathrm{N}=260)\end{array}$ & $\begin{array}{l}\text { L. Kyoga Basin wetland } \\
\text { system (Pallisa) }(\mathrm{N}=260)\end{array}$ & Pooled (520) \\
\hline More severe & $73(189) \mathrm{a}$ & $44(115)$ & $58(304) * * *$ \\
Less severe & $5(13)$ & $9(22)$ & $7(35)$ \\
Do not know & $22(58) \mathrm{b}$ & $47(123)$ & $35(181)+++$ \\
\hline
\end{tabular}

Figures in parentheses are number of households; $\left(\chi^{2}(2)=43.67, \mathrm{P}<0.001\right)$

$*, * *, * * *$ : Post hoc test statistically significant for category/cell "More severe" at $\mathrm{P}<0.05$

$(-1.96>\mathrm{Z}>+1.96), \mathrm{P}<0.01(-2.58>\mathrm{Z}>+2.58)$, and $\mathrm{P}<0.001(-3.29>\mathrm{Z}>+3.29)$

,,++++++ : Post hoc test statistically significant for category/cell "Do not know" at $\mathrm{P}<0.05$

$(-1.96>Z>+1.96), P<0.01(-2.58>Z>+2.58)$, and $P<0.001(-3.29>Z>+3.29)$

$\mathrm{Z}$ : Standardised residual $[\mathrm{P}<0.05(-1.96>\mathrm{Z}>+1.96), \mathrm{P}<0.01(-2.58>\mathrm{Z}>+2.58)$, and $\mathrm{P}<0.001$ $(-3.29>Z>+3.29)$ ] (Field, 2009). P-Value: for Pearson $\chi^{2}$ test. a,b More/fewer households observed than expected 


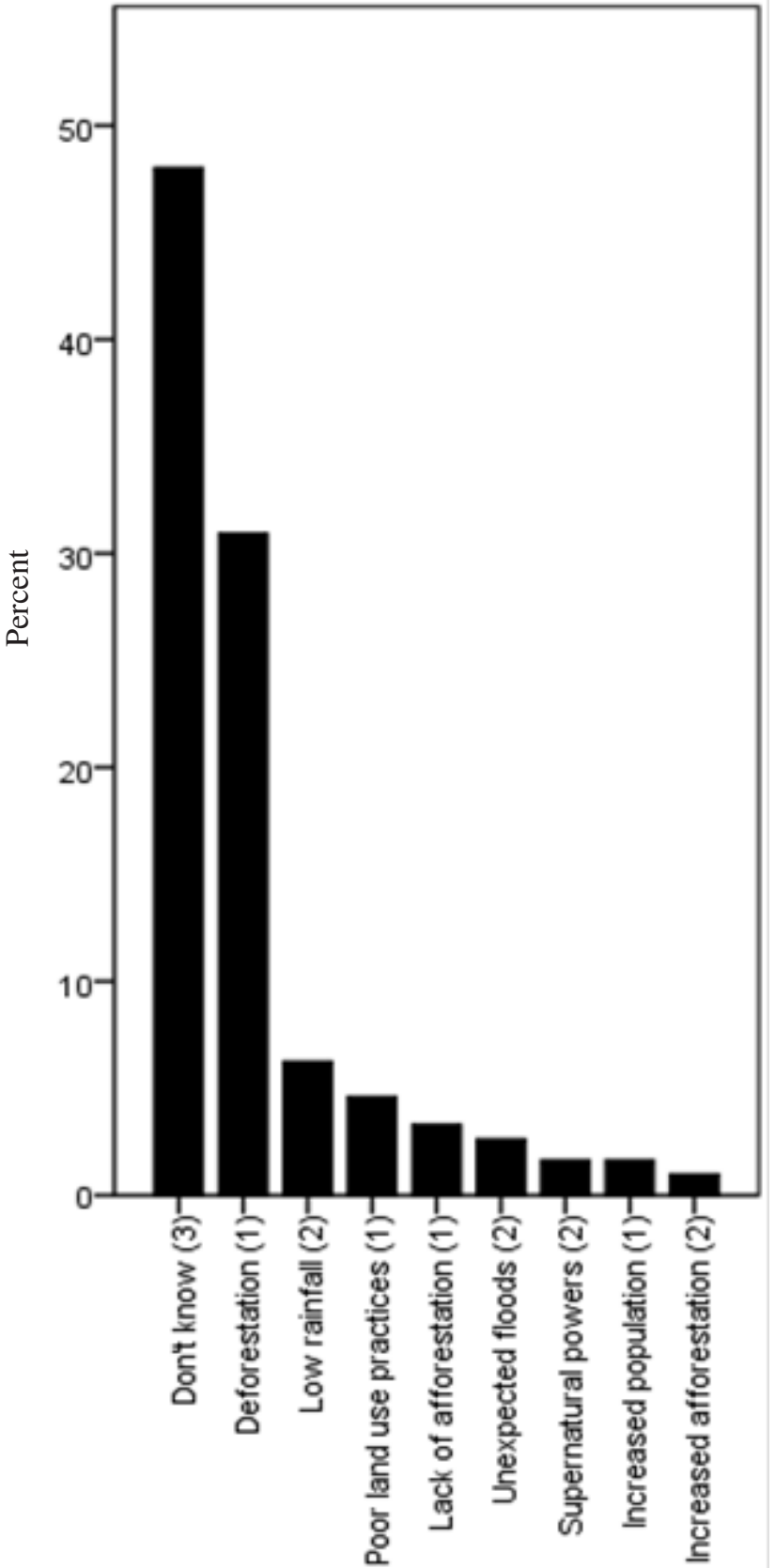

Reasons for household perception of more severe climate change in the future $(\mathrm{N}=304)$
Key

$1=$ Scientifically plausible $2=$ Scientifically implausible $3=$ Do not know

Figure 2. Reasons for household perception of more severe climate change in the future. 
climate change in the future with scientific climate change literature, the study shows that deforestation, poor land use practices, lack of afforestation, and increased human population were scientifically plausible reasons to worry about the severity of climate change in the future. On the other hand, low rainfall, unexpected floods, increased afforestation, and supernatural powers were scientifically wrong and simply superstitious in the case of the latter.

\section{Discussion}

\section{Perception of climate change}

It is not a surprise that households perceive climate change in terms of longer dry spells and hotter and drier seasons (Table 1) given that the study was conducted at sites located along the cattle corridor, which is prone to dry spells. According to the Isingiro District Planning Unit (2015), droughts have recently become more frequent in the district. Most likely, it is for this reason that only fewer households in L. Nakivale wetland areas had either not noticed climate change, or they did not at all know whether climate change had occurred in their area. The findings of the study regarding the trends in temperatures (increased or decreased temperature) over the past 30 years appear self-contradicting given that more households in L. Nakivale wetland areas did not know that temperatures had increased, and yet at the same time reported decrease in temperatures. Shifts in temperature from hot days to cool nights which is characteristic of temperature variations in semi-arid and arid areas (Peterson, 2018), explains such perception given that Isingiro lies in the semi-arid cattle corridor. Besides, people may be accustomed to the relatively high temperatures within the cattle corridor, and thus fail to properly discern any gradual increments in temperature for some time. Although the recall period for climate change spans three decades, perception of climate change may be influenced by recent events such as the increased frequency of droughts as reported by the Isingiro District Planning Unit (2015). Much as most (96\%) households in the L. Kyoga basin wetland areas in Pallisa district perceived increased temperatures, only $21 \%$ of them perceived reduction in temperature. The low elevation of Pallisa district (Nyasimi et al., , 2016) supports the perception of temperature reduction only by a small proportion of the households in Pallisa district.

The common perception that strong winds had become more frequent and more severe in Pallisa is attributed to deforestation and wetland degradation which strips the landscape of its protection from winds by vegetation. Whereas forests reduce the effects of wind by serving as windbreaks (Government of Uganda, 2007), wetland degradation through conversion for rice farming and deforestation due to clearance of swamp forests are major environmental challenges in Pallisa district (Nalukenge et al., 2009). For instance, by the year $2000,68 \%$ of the seasonal wetlands in Pallisa district were already converted for rice cultivation, and Isingiro was facing serious land degradation due to overutilisation (NEMA, 2000). However, being a part of the L. Mburo-Nakivale wetland system which is a Ramser site, restoration efforts through re-vegetation of L. Nakivale catchments especially through tree growing at the boundary of L. Nakivale and its wetlands have been made (NEMA, 2012), although restoration of the degraded wetlands remains a challenge 
(Isingiro District Planning Unit, 2015). In addition, lying next to L. Nakivale is L. Mburo National Park, a protected area that also serves as a wind break. It is therefore important that the local governments in both Pallisa and Isingiro districts strengthen efforts towards wetland conservation and promote sustainable land management through revegetation of degraded areas adjacent to wetlands especially through tree growing.

Generally, most households in Pallisa had a clearer perception of climate change than those in Isingiro district, given that out of the changes in climate properties and climate change effects under study, only $1 \%$ of them did not know whether rainfall had decreased (Table 2). This is because households in the wetland adjacent areas of Pallisa district are more vulnerable to climate change and its effects such as strong winds and floods than their counterparts in Isingiro districts owing to the flat topography of their landscape. Accordingly, Nanduddu (2010) reported that households in Gogonyo subcounty in Pallisa district were susceptible to flooding during rainy periods because of the generally flat terrain of the area. Furthermore, Nanduddu (2010) attributed household vulnerability to climate change effects to socio-economic factors such as wealth and household size, although she did not elaborate on the latter. She argued that household adaptive capacity in the form of wealth influences their perception of climate change risks such as dry spells as measured by the exposure or ranking of changes in climate parameters and climate change effects by the households. This suggests that the poor who often have low adaptive capacity (Government of Uganda, 2007) have a clear perception of climate change due to exposure to climate change effects. Given that Pallisa is poorer than Isingiro (UBOS, 2012), it is thus consistent that households in Pallisa had a clearer perception of climate change than their counterparts in Isingiro. In order to reduce vulnerability to climate change as a result of poverty, dependence on natural resources and subsistence farming, there is a need for households to commercialise agriculture and diversify their livelihoods.

This study attributes the perception of increased floods in the Kyoga plains to wetland degradation. According to the Government of Uganda (2016), frequent flash floods have become more severe in many parts of eastern Uganda because the massive overland flow of water during rainy periods is not absorbed by wetlands due to wetland degradation. Nanduddu (2010) attributed the flashfloods in Pallisa district to short intensive rains that increase the vulnerability of the area to changes in rainfall. Thus, restoration of the degraded wetlands should be pursued to mitigate the severe and destructive effects of floods in Pallisa district.

Again, households in the wetland adjacent areas in Isingiro district were not sure of whether droughts had become more frequent or more severe perhaps because of the generally semi-arid nature of the area. This is attributed to adoption of water harvesting and conservation technologies as a result of public programmes to minimize the effects of water stress in the area (Isingiro District Planning Unit, 2015). Given that food insecurity in this area was attributed to climate change (Turyahabwe et al., 2013), farmers have already adopted some adaptation strategies, including the use of wetlands, which at least temporarily cushions them against drought (Turyahabwe et al., 2013). 
Perception of climate change in the future

There is a gloomy outlook of the future of climate change, especially in Isingiro district, with a majority of them claiming that climate change will be more severe in the future. This is attributed to the recent experiences of increasing frequency of drought and water shortages in the district (Isingiro District Planning Unit, 2015). Indeed, according to Nuwagaba and Namateefu (2013), Isingiro is one of the districts in western Uganda that shoulders the consequences of changes in precipitation, water availability, and length of seasons thus affecting food security in the area.

Reflecting on the Millennium Ecosystem Assessment (MEA) report (MEA, 2005a), the fact that wetlands are being rapidly lost, and that climate change is bound to worsen the degradation and loss of wetlands, and vice versa shades more light on the worrying perception of the future of climate change. Furthermore, within the frame of the IPCC (2007), where climate change is bound to continue, especially due to anthropogenic interferences with the carbon cycle, it is argued that climate change could indeed become more severe in the future due to the ongoing wetland degradation.

Projection of the future of climate change by the IPCC in its Fifth Assessment Report (AR5) is that under all assessed greenhouse gas emission scenarios, surface temperature will rise over the $21^{\text {st }}$ century (IPCC, 2014). Relative to the period 1986-2005, the global mean surface temperature for the period 2016-2035 is expected to rise by a range of $0.3^{\circ} \mathrm{C}$ to $0.7^{\circ} \mathrm{C}$ for all considered scenarios. In addition to more frequent and longer lasting heat waves, the IPCC also projects more frequent and intense extreme precipitation events in this century in many regions (IPCC, 2014). Therefore, proper management of wetlands, watersheds and reservoirs is important for improving adaptation to climate change (IPCC, 2014).

Households from both Isingiro and Pallisa who perceived climate change to be more severe in the future, but had no particular reason to explain their perception, and those who on the basis of scientific literature hold scientifically doubtful reasons for their pessimistic view of the future of climate change pose real threats to the sustainable use of wetland resources. These groups of households are bound to use or attempt to secure wetlands for future adaptation to climate change. The problem, however, is that unlike those with scientifically sound reasons (Fig. 2) for their perception of a more severe climate change in the future, they may adapt in ways that actually exacerbate the severity of climate change.

As Maddison (2007) reported, adaptation to climate change is a two stage process; that is, households first perceive climate change before adapting to it. Thus, this study contends that households who had a sound reason to back their perception of a more severe climate change are better placed to adopt climate change adaptation strategies for improving their livelihoods. Such strategies may for example include minimum tillage in wetland areas and water conservation practices. Selection of sites from two agroecological zones where wetlands are being degraded by agricultural activities (Mafabi, 2000) is useful for proper targeting of interventions. 


\section{Conclusion}

Households in the wetland adjacent areas of Uganda are generally aware about climate change manifested in the forms of prolonged dry weather, and hotter and drier seasons. The major changes perceived in the climate properties were increased temperature, decreased rainfall, changes in the length of seasons, and more frequent and severe droughts. Although food production in wetland areas already contributes significantly to wetland degradation, the extreme weather events such as drought reported in this study suggest that farming in wetland adjacent areas still suffers a lot from water stress, implying a growing pressure to use wetlands for food production. Moreover, prospects for the future of food security in the wetland areas are not impressive given the pessimistic view household's hold of climate change in the future.

In order to avert further wetland degradation as a result of pressures to use wetlands for food security and climate change adaptation, farmers adjacent to wetland areas need to adopt climate smart and conservation friendly food production practices such as minimum tillage, soil and water conservation, commercially viable food production interventions such as fish farming. Sensitization on climate change will be useful for farmers to adopt such practices.

\section{Acknowledgement}

The authors are grateful to the International Development Research Center (IDRC) for funding this research and the German Academic Exchange Service (DAAD) for supplementary financial support.

\section{References}

Alelign, A., Yemshaw, Y., Teketay, D. and Edwards, S. 2011. Socio-economic factors affecting sustainable utilization of woody species in Zegie Peninsula, northwestern Ethiopia. Tropical Ecology 52(1): 13-24.

Bartlett, J.E., Kotrlik, J.W. and Higgins, C.C. 2001. Organizational research : Determining appropriate sample size in survey research. Information Technology, Learning, and Performance Journal 19(1):43-50.

Denboba, M.A. 2005. Forest conversion - soil degradation - farmers' perception nexus: Implications for sustainable land use in the southwest of Ethiopia. Ecology and Development Series No . 26. Bonn, Germany.

Deressa, T.T., Hassan, R.M. and Ringler, C. 2011. Perception of and adaptation to climate change by farmers in the Nile basin of Ethiopia. Journal of Agricultural Science 149:23-31. https://doi.org/10.1017/S0021859 610000687

Ebanyat, P., de Ridder, N., de Jager, A., Delve, R. J., Bekunda, M. A. and Giller, K.E. 2010. Drivers of land use change and household determinants of sustainability in smallholder farming systems of Eastern Uganda. Population and Environment 31(6): 474-506. https://doi.org/10.1007/ s11111-010-0104-2

Godfray, H. C. J., Beddington, J. R., Crute, I. R., Haddad, L., Lawrence, D., Muir, J. F. and Toulmin, C. 2010. Food security: the challenge of feeding 9 billion people. Science 327(5967): 812-8. https://doi.org/10.1126/science. 1185383 
Godfray, H.C.J. and Garnett, T. 2014. Food security and sustainable intensification Food security and sustainable intensification. Philosophical Transactions of the Royal Society B 369: 1-10.

Government of Uganda. 2007. Climate Change: Uganda National Adaptation Programmes of Action. Kampala. Retrieved from http://unfccc.int/ resource/docs/napa/uga01.pdf

Government of Uganda. 2016. Uganda Wetlands Atlas Volume Two: Popula Version. Kampala, Uganda: Government of Uganda.

Handmer, J., Yasushi, H., Kundzewicz, Z. W., Arnell, N., Gerardo, B., Hatfield, J. and Yan, Z. 2012. Changes in impacts of climate extremes: human systems and ecosystems. In: D.Q. Field, C.B., V. Barros, T.F. Stocker, P. M. M. D.J. Dokken, K.L. Ebi, M.D. Mastrandrea, K.J. Mach, G.-K. Plattner, S.K. Allen and M. Tignor (Eds.), Managing the Risks of Extreme Events and Disasters to Advance Climate Change Adaptation. pp. 231290). Cambridge, UK, and New York, NY, USA: Cambridge University Press. Retrieved from https:// www.ipcc.ch/pdf/special-reports/srex/ SREX-Chap4_FINAL.pdf

Hansen, J., Sato, M. and Ruedy, R. 2012. Perception of climate change. PNAS, E2415-E2423. https://doi.org/10.1073/ pnas. 1205276109

Horwitz, P. and Finlayson, C.M. 2011. Wetlands as settings for human health: Incorporating ecosystem services and health impact assessment into water resource management. BioScience 61(9):678-688. https://doi.org/10.1525/ bio.2011.61.9.6

Horwitz, P., Finlayson, C.M. and Weinstein, P. 2012. Healthy wetlands, healthy people: A review of wetlands and human health interactions (Ramsar Technical Report No. 6). Gland, Switzerland. Retrieved from http:// www.ramsar.org/sites/default/files/ documents/pdf/lib/rtr6-health.pdf

IPCC. 2007. Climate Change 2007: Synthesis Report. Contribution of Working Groups I, II and III to the Fourth Assessment Report of the Intergovernmental Panel on Climate Change. R. Pachauri and A. Reisinger, (Eds.). Geneva, Switzerland: IPCC.

IPCC. 2014. Climate Change 2014/: Contribution of Working Groups I, II and III to the Fifth Assessment Report of the Intergovernmental Panel on Climate Change Synthesis Report. Contribution of Working Groups I, II and III to the Fifth Assessment Report of the Intergovernmental Panel on Climate Change.

Isingiro District Planning Unit. 2015. Five Year District Local Government Development Plan II 2015/2016-2019/ 2020. Isingiro Town: Isingiro District Local Government.

Jones, L. 2010. Overcoming social barriers to climate change adaptation Background paper published by ODI. London.

Kisauzi, T., Mangheni, M.N., Sseguya, H., and Bashaasha, B. 2012. Gender dimensions of farmers' perceptions and knowledge on climate change in Teso sub-region, Eastern Uganda. African Crop Science Journal 20(2):275286.

Kuperman, A.J. 2011. Can political institutions avert violence? TEXAS: Climate Change and African Political Stability (CCAPS) Program. Retrieved from https://www.files.ethz. ch/isn/133055/2011-08.pdf 
Lobell, D.B., Schlenker, W. and CostaRoberts, J. 2011. Climate trends and global crop production since 1980 . Science, 333(616). https://doi.org/ 10.1126/science. 1204531

Maddison, D. 2007. The perception of and adaptation to climate change in Africa (Development Research Group Sustainable Rural and Urban Development Team No. 4308). Africa. Birmingham, UK. https://doi.org/http:/ /elibrary.worldbank.org/doi/pdf/ 10.1596/1813-9450-4308

Mafabi, P. 2000. The role of wetland policies in the conservation of waterbirds/ : The case of Uganda. Ostrich/ : Journal of African Ornithology 71(1-2):96-98. https:// doi .org/10.1080/00306525. 2000.9639880

Magnani, R. 1997. Sampling Guide. Food and Nutrition Technical Assistance Project (FANTA). Washington, DC 20009-5721.

McKinney, P. 2009. Comprehensive Food Security \& Vulnerability Analysis: Uganda. World Food Programme, VAM Food Security Analysis Cover. Rome, Italy. Retrieved from http:// home.wfp.org/stellent/groups/public/ documents/ena/wfp202495.pdf

MEA. 2005a. Ecosystems and Human Well-being/ : Wetlands and Water Synthesis. Regions and Cohesion (Vol. 13). Washington, DC: World Resources Institute. https://doi.org/ 10.1017/CBO9781107415324.004

MEA. 2005b. Ecosystems and Human well-being: Health Synthesis - a report of the Millennium Ecosystem Assessment. World Health. Geneva, Switzerland. https://doi.org/10.1196/ annals. 1439.003

Mearns, R. and Norton, A. 2010. Equity and vulnerability in a warming world:
Introduction and overview. In: R. Mearns and A. Norton (Eds.), Social Dimensions of Climate Change: Equity and Vulnerability in a Warming World. pp. 1-319. Washington, DC: World Bank.

Mertz, O., Mbow, Æ. C. and Reenberg, Æ. A. 2009. Farmers ' Perceptions of Climate Change and Agricultural Adaptation Strategies in Rural Sahel. Environmental Management, 43, 804-816. https://doi.org/10.1007/ s00267-008-9197-0

Ministry of Water and Environment. 2012. Uganda National Climate Change Policy. Kampala, Uganda: Ministry of Water and Environment.

Nalukenge, I., Antle, J. M. and Stoorvogel, J. 2009. Assessing the feasibility of wetlands conservation: Using payments for ecosystem services in Pallisa, Uganda. In: L. Lipper, T. Sakuyama, R. Stringer, and D. Zilberman (Eds.), Payment for Environmental Services in Agricultural Landscapes: Economic Policies and Povert Reduction in developing Countries 31:239-253). Rome, Italy: Springer Science and Business Media, LLC. https://doi.org/ 10.1007/978-0-387-72971-11

Nanduddu, S. 2010. Community Based Adaptation to Climate Change in Africa (CBAA). Lived Experiences: Adaptation to Climate Change in Gogonyo Sub-County, Palisa District, Uganda. Kampala, Uganda.

Ndambiri, H. K., Ritho, C. N. and Mbogoh, S. G. 2013. An evaluation of farmers' perceptions of and adaptation to the effects of climate change in Kenya. International Journal of Food and Agricultural Economics 1(1):75-96. Retrieved from http://foodand agriculturejournal.com/75.pdf 
NEMA. 2000. State of the Environment Report for Uganda, 2000/2001. Kampala, Uganda.

NEMA. 2012. National State of the Environment Report for Uganda 2012: Harnessing our environment for wealth creation. Kampala, Uganda.

Nuwagaba, A. and Namateefu, L.K. 2013. Climatic change, land use and food security in Uganda: A survey of Western Uganda 3(2):61-72.

Nyasimi, M., Radeny, M., Mungai, C. and Kamini, C. 2016. Uganda's National Adaptation Programme of Action: Implementation, Challenges and Emerging Lessons. Copenhagen, Denmark. Retrieved from www.ccafs. cgiar.org

Olorunfemi, F. 2009. Risk communication in climate change and adaptation: Policy issues and challenges for Nigeria. In: IOP Conference Series: Earth and Environmental Science 6: p. 1. https://doi.org/10.1088/17551307/6/1/412036

Peterson, J. 2018. Characteristics of a dry climate. Retrieved July 19, 2018, from https://sciencing.com/characteristicsdry-climate-4878.html

Turyahabwe, N., Kakuru, W., Tweheyo, M. and Tumusiime, D.M. 2013. Contribution of wetland resources to household food security in Uganda. Agriculture \& Food Security 2(1):15. https://doi.org/10.1186/2048-7010-25

UBOS. 2012. Uganda Poverty Maps 2012/2013. Kampala, Uganda: Uganda Bureau of Statistics.

WMD, MoWE, UBOS, ILRI and WRI. 2009. Mapping a better future how spatial analysis can benefit wetlands and reduce poverty in Uganda. Washington, DC and Kampala: World Resources Institute. 